\title{
HUBUNGAN ANTARA KEMATANGAN EMOSI DENGAN PENYESUAIAN DIRI PADA REMAJA
}

\section{DWI SARI USOP}

Dosen Pada Program Studi Bimbingan dan Konseling Fakultas Keguruan dan Ilmu Pendidikan Universitas Muhammadiyah Palangkaraya

\begin{abstract}
ABSTRAK
Masa remaja adalah suatu masa yang unik dalam fase kehidupan remaja, di mana seorang yang telah memasuki usia remaja memiliki karakteristik yang khas. Dengan karakter yang khas tersebut, remaja dituntut untuk mampu menyesuaikan diri dengan baik terhadap individu di sekitarnya. Akan tetapi, tidak semua remaja mempunyai penyesuaian diri yang baik. Hal ini menjadi salah satu kendala dalam kehidupan remaja untuk menuju kehidupan yang sehat. Salah satu kendala lainnya adalah masalah kematangan emosi, sebab masih banyak remaja yang belum memiliki kematangan emosi yang baik.

Penelitian ini bertujuan untuk mengetahui hubungan antara kematangan emosi dengan penyesuaian diri di SMPN 19 Surabaya. Populasi penelitian adalah seluruh peserta didik kelas VIII yang berjumlah 261 orang dan sampel berjumlah 106 peserta didik. Teknik sampling yang digunakan dalam penelitian ini adalah non random sampling dengan teknik pengumpulan data berupa angket yang disusun berdasarkan Skala Likert.

Penelitian menunjukkan hasil yang sangat signifiikan, di mana nilai $r=0,809$ dengan $p=0,000(p<$ 0,010). Hal ini berarti hipotesis yang diajukan diterima. Kematangan emosi mempunyai hubungan yang sangat signifikan dengan penyesuaian diri pada remaja di SMPN 19 Surabaya
\end{abstract}

Kata Kunci : Penyesuaian diri, Kematangan emosi, Remaja

\section{PENDAHULUAN}

Masa remaja adalah suatu masa yang unik. Usia seorang anak memasuki masa remaja berbeda-beda. Mappiare (dalam Ali dan Asrori, 2005), mengungkapkan bahwa masa remaja adalah berlangsung antara usia 12-21 tahun bagi wanita dan 13-22 tahun bagi pria. Sedangkan Monks, dkk (2002), mengungkapkan tiga kategori batasan usia remaja, yaitu : a). remaja awal dengan batasan usia 12-15 tahun, b). remaja pertengahan dengan batasan usia 15-18 tahun, c). remaja akhir dengan batasan usia 18-21 tahun.

Piaget (dalam Hurlock, 1999), mengungkapkan bahwa masa remaja adalah usia di mana individu berintegrasi dengan masyarakat dewasa, usia di mana anak tidak lagi merasa di bawah tingkat orang yang lebih tua melainkan berada dalam tingkatan yang sama, sekurang- kurangnya dalam masalah hak. Hal ini menuntut kemampuan remaja untuk menyesuaikan diri dengan individu-individu lain dan kondisi lingkungan di sekitarnya.

Kemampuan menyesuaikan diri tersebut akan memberikan dampak positif bagi remaja, sebab seorang remaja yang mampu menyesuaikan diri akan dapat menghadapi suatu masalah melalui cara yang tepat. Suatu cara yang menguntungkan diri sendiri dan tidak merugikan orang lain. Menurut Sawrey dan Telford (dalam Windriani, 2006), menyebutkan ada beberapa kriteria remaja yang mampu menyesuaikan diri, yaitu sering merasa gelisah, memiliki rasa toleransi, otonomi diri, integritas kepribadian, harga diri yang tinggi, serta mampu mengaktualisasikan diri.

Pernyataan Sawrey dan Telford tersebut sesuai dengan pengertian penyesuaian diri yang 
dikemukakan oleh Puspito (1991), yaitu penyesuaian diri merupakan suatu proses sosial yang di dalamnya ada dua atau lebih individu atau kelompok berusaha untuk tidak saling mengganggu dengan cara mencegah, mengurangi, atau menghentikan ketegangan yang akan timbul atau yang sudah ada. Pengertian penyesuaiann diri tersebut didukung oleh Wiehartoningsih (1993) yang menungkapkan bahwa penyesuaian diri merupakan suatu proses yang dialami oleh individu dalam usaha mempertahankan keseimbangan fisiologis dan psikologis, serta mendorong individu tersebut untuk mengaktualisasikan dirinya.

Namun demikian, tidak semua remaja mampu menyesuaikan diri dengan tepat. Hal ini dapat dikaitkan dengan karakteristik diri remaja itu sendiri, yang cenderung melakukan pertentangan khususnya dengan orang tua, senang mengkhayal akan keinginan-keinginan yang belum terpenuhi, senang melakukan aktivitas bersama-sama teman, dan senang mencoba segala sesuatu (Ali dan Asrori, 2005). Remaja yang belum dapat menyesuaikan diri dengan baik adalah remaja yang tidak dapat bertanggung jawab, bersikap agresif, suka berkhayal, menghindar dari masalah, selalu bergantung pada orang lain atau orang tua, bersikap kekanakkanakan dan mudah menyerah.

Masalah lain yang dialami remaja berkaitan dengan kematangan emosi. Kematangan emosi merupakan suatu kedewasaan seseorang dalam berpikir secara objektif yang dimanifestasikan dalam perilaku yang wajar dan sesuai dengan fakta yang ada. Semiun (2006), mengungkapkan pengertian kematangan emosi adalah kemampuan seseorang untuk bereaksi dalam berbagai situasi kehidupan dengan cara-cara yang lebih bermanfaat dan bukan dengan caracara bereaksi seorang anak.

Seorang remaja yang matang emosinya, akan meledakkan emosinya pada saat yang tepat dan waktu yang tepat pula. Bila seorang remaja memiliki emosi yang stabil, maka ia mampu mengadakan kompromi atau penyesuaian diri terhadap sesuatu yang diinginkan dengan fakta yang ada sehingga dapat menghadapi masalah dengan tenang Bagi remaja yang menghadapi suatu permasalahan sehingga membangkitkan emosinya dan tidak dapat mengendalikannya, maka remaja tersebut dikatakan belum memiliki emosi yang matang.

Berdasarkan uraian dui atas, Peneliti tertarik untuk mengetahui hubungan antara kematangan emosi dengan penyesuaian diri pada remaja.

\section{HIPOTESIS}

Hipotesis penelitian yang diajukan adalah ada hubungan antara kematangan emosi pada remaja dengan penyesuaian diri.

\section{METODE PENELITIAN}

Populasi dalam penelitian ini adalah seluruh peserta didik kelas delapan SMPN 19 Surabaya yang berlokasi di Jl. Arief Rachman Hakim No. 103B. Populasi berjumlah 261 siswa yang terbagi dalam tujuh kelas, yaitu kelas VIII A - kelas VIII G. Jumlah sampel penelitian yang akan diteliti adalah 106 siswa yang terbagi atas tiga kelas, yaitu kelas VIII D, kelas VIII E, dan kelas VIII G dengan jumlah siswa masing-masing kelas adalah sebagai berikut : a). kelas VIII $D$ berjumlah 38 siswa, b). kelas VIII E berjumlah 32 siswa, dan c). kelas VIII G berjumlah 36 siswa. 
Dengan demikian, jumlah subyek yang akan dijadikan sampel penelitian adalah 106 siswa.

Teknik sampling yang digunakan dalam penelitian ini adalah non random sampling karena sampel penelitian ditentukan berdasarkan penunjukan oleh pihak sekolah dengan teknik pengumpulan data menggunakan angket. Ada dua angket yang digunakan, yaitu angket kematangan emosi dan angket penyesuaian diri. Kedua angket ini disusun berdasarkan Skala Likert dengan empat alternatif jawaban, yakni sangat setuju, setuju, tidak setuju, dan sangat tidak setuju.

Materi dari skala yang disusun dalam bentuk pernyataan-pernyataan yang terdiri atas dua jenis pernyataan, yaitu pernyataan yang mendukung (favourable) dan pernyataan yang tidak mendukung (unfavourable). Keduanya mempunyai sistem penilaian yang berbeda. Penilaian untuk pernyataan yang mendukung (favourable) adalah sangat setuju (SS) diberi nilai 4, setuju (S) diberi nilai 3, tidak setuju (TS) diberi nilai 2, dan sangat tidak setuju (STS) diberi nilai 1. Sebaliknya pernyataan yang unfavourable, sangat setuju (SS) diberi nilai 1, setuju (S) diberi nilai 2, tidak setuju (TS) diberi nilai 3, dan sangat tidak setuju (STS) diberi nilai 4.

Untuk mengukur kematangan emosi digunakan skala kematangan emosi yang disusun berdasarkan teori yang diungkapkan oleh Mappiare yang dikutip dari Ramadhani (2002). Empat aspek yang diukur adalah rasa kasih sayang, emosi terkendali, emosi terbuka lapang, dan emosi terarah. Sedangkan penyesuaian diri diukur dengan menggunakan skala penyesuaian diri yang disusun berdasarkan teori Sawrey dan Telford yang dikutip dari Windriani (2006), yaitu toleransi, otonomi diri, integrasi kepribadian, harga diri, dan aktualisasi diri.

Teknik analisa data yang digunakan adalah korelasi product moment yang penghitungannya dilakukan dengan menggunakan jasa program komputer SPSS 12,0 for windows.

\section{HASIL PENELITIAN}

Dari hasil analisis data diperoleh nilai $r=$ 0,809 dengan $p=0,000(p<0,010)$ yang berarti ada korelasi yang sangat signifikan antara kematangan emosi dengan penyesuaian diri. Penjelasan secara rinci tentang korelasi antara kematangan emosi dengan penyesuaian diri, tertuang dalam tabel di bawah ini :

Tabel Hasil Analisis Data Product Moment

\begin{tabular}{|l|l|l|l|l|}
\hline Statistik & & & $\mathrm{P}$ & Keterangan \\
\hline $\mathrm{xy}$ & 0,809 & 0,000 & $\mathrm{P}<0,010$ & $\begin{array}{l}\text { Sangat } \\
\text { Signifikan }\end{array}$ \\
\hline
\end{tabular}

Berdasarkan tabel di atas, diketahui nilai $r$ sebesar 0, 809 dengan signifikansi 0,000. Nilai signifikansi ini berada di bawah 0,010 yang berarti hipotesis yang diajukan diterima. Dengan demikian, dapat disimpulkan bahwa ada hubungan yang sangat signifikan antara kematangan emosi dengan penyesuaian diri pada remaja di SMPN 19 Surabaya.

\section{DAFTAR PUSTAKA}

Ali, Mohammad \& Asrori, M. (2005). Psikologi Remaja - Perkembangan peserta Didik. Jakarta : PT. Bumi Aksara

Hurlock, E. B. (1999). Psikologi Suatu Pendekatan Sepanjang Rentang Kehidupan. Jakarta : Erlangga

Monks, dkk. (2002) Psikologi Perkembangan Pengantar Dalam Berbagai Bagiannya. Yogyakarta : Gadjah Mada University Press 
Puspito, H. (1991). Tanya jawab Sosiologi. Jakarta : PT. Gramedia Widia Sarana IndonesiaRamadhani, F. 2002. Hubungan Antara Kematangan Emosi dengan Kenakalan Remaja di SMKN II Bangkalan. Skripsi. Fakultas Psikologi UPB. Surabaya. Tidak diterbitkan

Semiun. (2006). Kesehatan Mental 1. Kanisius : Yogyakarta

Wiehartoningsih. (1993). Peranan Keluarga Memandu Anak. Jakarta : CV. Rajawali

Windriani, I. (2006). Hubungan antara Konsep Diri dengan Penyesuaian diri pada Remaja Kelas 1 SMU Dharma Wanita Kota Surabaya. Skripsi. Fakultas Psikologi UPB. Surabaya. Tidak diterbitkan 